\title{
The national green tribunal in Indian perspective
}

\section{Introduction}

The environmental disputes are typical and complicated in nature so it requires an expertise in different fields (like biology, sociology, economics, administration, management and law etc.) to resolve the environmental matters in effective and expeditious manner which is not possible with a regular judicial and administrative set up in India In other words, the environmental disputes related to forest, biodiversity, air and water are complicated in nature to resolve this type of problem and expeditious disposal of case is not possible without separate special court. The necessity of environmental court has been long demanded for other reason like....the Indian judiciary is over burdened with a large number of pending cases. ${ }^{1}$ On this context, to effective prevention and control of environmental pollution, there was an urgent need for a separate environmental court to decide the case without much delay. ${ }^{1}$ India is a party to the united nation conference on the human environment popularly known as Stockholm Conference, 1972 has made significant declaration related to safeguarding of natural resources and to developing international law, to provide compensation for the victim of pollution and other environmental degradation. ${ }^{2}$

The second United Nation Conference on the environmental and development conducted at Rio-De-jenerio in 1992.India is also a signatory of this declaration. This declaration states that, the participatory states must make suitable environment legislation regarding with effective access to the peoples of country in judicial and administrative proceeding including remedies. ${ }^{3}$ The Law Commission of India in its $186^{\text {th }}$ report recommended that the Union government should be establish and constitute Separate Environmental Court in each state, to deal with complex scientific and specialized issue relating to environment. This type of court manned only by the person having scientific qualification and experience in judicial or legal field. Environmental court at the level of each state should be accessible to the litigants. Environmental court should exercise original as well as appeallate jurisdiction related to substantial question of environment and in various other statutes. ${ }^{4}$

The Prominent jurist of the country also expressed the similar views. ${ }^{5}$ To give effect of aforesaid declaration and recommendations

${ }^{1}$ The Indian Apex court opined in MC Mehta v Union of India AIR (1987) sc popularly known as Oleum Gas Leak case, that it would be desirable to have the setting up of "environmental courts on the regional basis with a professional judge and two experts drawn from the Ecological science research group.

${ }^{2}$ Prasad PM. "Environmental Protection; Role of Regulatory System in India (Ed.2006).

${ }^{3}$ See, Report and principle 13 of Rio-de-jenerio conference on Environment and Development, 1992.

${ }^{4}$ Law commission of India, $186^{\text {th }}$ report.

${ }^{5}$ Prof. Upendra Baxi has expressed the view that a single judicial forum with jurisdiction under the environment act and other related environmental acts over both criminal prosecution and civil claims for violation of the laws should be established. From this forum, appeals could go to an appeallate court of the status of High court with the facility of another appeal to the Supreme Court under article 136 of the constitution of India. He was also of the opinion that victim groups and public interest group should have access to these to
Volume 7 Issue 5 - 2019

\author{
Vivek Dubey \\ Assistant Professor, Department of Law, Dr. Harisingh Gour \\ Vishwavidyalaya Sagar University, India
}

Correspondence: Vivek Dubey, Assistant Professor, Department of Law, Dr. Harisingh Gour Vishwavidyalaya Sagar University, India,Tel 8358800320,Email vivekdub@gmail.com

Received: August 23, 2019 | Published: September II, 2019

and to provide for a separate special court for effective and expeditious disposal of cases relating to environment, relief, compensation, damages to the person or property, the Indian parliament enacted the National Green Tribunal Act, 2010. It has come into force on 2 June 2010. ${ }^{6}$ This Act has been repeal the National Environment Tribunal Act, 1995 and the National Environment Appeallate Authority Act, 1997 and saving the all pending cases before the National environmental appeallate authority. ${ }^{7}$ This Act seek to amend in various enactment and added provision related to appeal before NGT. These are following enactments: ${ }^{8}$

Added new section 33-B in The Water (Prevention and Control of pollution) Act, 1974.

Added new section 13-A in The Water (Prevention and Control of pollution) cess Act, 1977.

Added new section 2-A in The Forest (Conservation) Act, 1980.

Added new section 31-B in The Air (Prevention and control of pollution) Act, 1981.

Added new section.5-A in The Environment (Protection) Act, 1986.

Added new section 52-A in The Biological Diversity Act, 2002.

\section{Purpose and needs}

The purpose and needs to establishing NGT are as follows:

these courts. See, U. Baxi, Environmental protection Act: An agenda for implementation, 10(1987): see also G sadasivam Nair, Environmental offence: Crime against Humanity, in P. leelakrishnan, Law and environment, 186 (1992).

${ }^{6}$ The immediate reasons that prompted the Indian parliament To enact the Tribunal Act had been 1. The ordinate delay involved in the redressal of environment related grievances like the one involving the( Bhopal gas leak case) Charan lal sahu v. Union of India AIR 1990 SC 1480 and 2. The inadequacy of the existing judicial system to provide Adequate relief as evidenced in the (Oleum Gas Leak case) MC Mehta v. Union of India AIR 1987 SC 965.

${ }^{7}$ Sec. 38 of the NGT Act, 2010.

${ }^{8}$ Schedule-3 of the NGT Act 2010. 
i. To settling question and disputes where a substantial question relating to environment is involved. ${ }^{9}$

ii. To provide early and efficacious disposal of cases and also play twin purpose: Firstly, litigant satisfaction and Secondly, sustainable development with the due protection of environment.

iii. To provide affordable, accessible, quick and speedy justice in case relating to environment conservation and protection at the grass root level. ${ }^{10}$

iv. To provide compensation, damages, fine, relief to the person and property and restoration of ecology accordance with the polluter pay principle, precautionary principle and environmental doctrines. ${ }^{11}$

v. Its aim to establish to reduce the burden and pressure on the courts. ${ }^{12}$

vi. Any other matters related to environment and ecology.

\section{Salient features of NGT act 2010}

This act provides an important definitions like...Accident, environment, expert members, handling hazardous substance, injury, judicial member, substantial question relating to environment. ${ }^{13}$ The Central government shall have power to establish tribunal according to this Act. ${ }^{14}$ From the date of establishment the NGT is bound to hear complaints and settle dispute related to environment. While entertaining with complaints and settle dispute it is neither bound to follow the procedure laid in the code of civil procedure, 1908 nor bound by the rules of evidence contained in the Indian evidence act, 1872. But this Act allows to tribunal to follow the principle of natural justice. $^{15}$

i. The tribunal shall consist of a full time Chairperson and full time judicial and expert member. Members of tribunal shall minimum 10 and maximum 20 in number from each judicial and expert member. $^{16}$

ii. The Chairperson, judicial members and expert members shall be appointed by central government in consultation with the chief justice of India and the judicial members and expert

\footnotetext{
${ }^{9}$ See, Sec. 14(1), sec. 2(m) provides inclusive definition of "substantial question relating to environment", it shall include direct violation of a specific statutory environmental obligation by a person, by which the community at large other than an individual or group of individual is affected, the gravity of damage to the environment or property is substantial and the damage to public health is broadly measurable and also include the environmental consequences related to a specific activity or a point source of pollution.

${ }^{10}$ See, Law commission of India, $186^{\text {th }}$ report, Chapter- 10.

${ }^{11}$ NGT international journal on environment, vol-1 (2014) editorial note by Sheetal Sharma (dy. Registrar).

${ }^{12}$ Founded on basis of Judgement delivered by the Supreme Court of India in MC Mehta v. Union of India 1996 (3) SCC 212.

${ }^{13} \mathrm{Sec} .2$ of The NGT Act, 2010.

${ }^{14}$ The Gazette of India; Extraordinary part-2, Section 3(2), 2011 The Central Government (Ministry of environment and forest) specifies by notification in official gazette dated $17^{\text {th }}$ august 2011 , place of sitting of tribunal divided into five zones with territorial jurisdiction.

${ }^{15}$ See, Sec. 3 and 19 of this Act.

${ }^{16}$ See, Sec. 4 of this Act.
}

members shall be appointed on the recommendation of selection committee. ${ }^{17}$

iii. The term of office of chairperson, judicial member and expert members shall be five years or retirement age, whichever is earlier, prescribed by this act. ${ }^{18}$

iv. The Tribunal shall have as the power of civil court to passing any order or decision or award. While passing any order or decision or award, he must apply the principle of sustainable development, the precautionary principle and the polluter pay principle. ${ }^{19}$

v. This Act also provides the appeal and review provisions .Any aggrieved person may appeal before Supreme Court against the tribunals order or decision or award. The tribunal shall have power to review its own decision. ${ }^{20}$

vi. The tribunal shall have power to take cognizance of offence and impose penalty for failure to comply with any order or award or decision. $^{21}$

\section{Jurisdiction of NGT under the national green tribunal act, 2010}

The NGT Act provides two types of jurisdiction namely, 1.Original jurisdiction 2.Appeallate jurisdiction.

As per original jurisdiction the tribunal has jurisdiction of all civil cases where a substantial question relating to environment (including enforcement of any legal right relating to environment) involved and also question arises out of the implementation of Schedule-1.22

Schedule-1 talks about following enactments namely;-

i. The Water (Prevention and Control of Pollution) Act, 1974;

ii. The Water (Prevention and Control of Pollution) Cess Act, 1977;

iii. The Forest (Conservation) Act,

iv. The Air (Prevention and Control of Pollution) Act, 1981;

v. The Environment (Protection) Act, 1986;

vi. The Public Liability Insurance Act, 1991;

vii. The Biological Diversity Act, 2002.

The Act mandates on the Tribunal to hear the dispute arising under section 14(1) and also settle such dispute and pass order there on. But tribunal may adjudicate the dispute with in a period of 6 months from the date of which the cause of action first arose..$^{23}$

The tribunal shall also have appeallate jurisdiction enactments given under Schedule-1 of this act. As pre section 15 of this act, the relief, compensation and restitution, the tribunal may provide by an order:

\footnotetext{
${ }^{17}$ See, Sec. 6 of this Act.

${ }^{18}$ See, Sec.7 of this Act.

${ }^{19}$ See, Sec. 19 and 20 of this Act.

${ }^{20}$ See, Sec. 19 and 22 of this Act.

${ }^{21}$ See, Sec. 30 and 26 of this Act.

${ }^{22}$ See, Sec. $14(1)$ of this Act.

${ }^{23}$ See, proviso of Sec. 16 of this Act.
} 
a. To the victims of pollution and other environmental damage arising under Schedule-1 (including accident while handling any hazardous substance) of this act,

b. For restitution of property damaged,

c. For restitution of environment for such area or areas; Subject to the discretion of tribunal.

It is mandatory on tribunal, to pay and payable relief, compensation or restitution with addition to the relief given under the Public liability insurance Act, $1961 .{ }^{24}$ The application for any relief, compensation or restitution shall be ascertained by tribunal with in a period of 5 years from the date on which the cause of such compensation or restitution first arise. On the satisfaction of sufficient cause the tribunal may further extend 60 days to file the application. ${ }^{25}$

\section{Bar of jurisdiction}

The Civil court shall not interfere with the appeallate jurisdiction of tribunal, where the matter or question related to settling dispute or claim or relief or compensation or restitution of property damaged or environmental damaged involved and which may be adjudicated upon by the tribunal. ${ }^{26}$

\section{Appeal to the Supreme Court}

The Appeal may file before the Supreme Court against any award or decision or order of the tribunal, by any aggrieved person within 90 days from the date of communication of the award or decision or order of the tribunal on any grounds provided in Section.100 of The code of civil procedure 1908. Further this act provide discretionary power of supreme court related to appeal, after the expiration of aforesaid period (90 days) the supreme court may entertain any appeal if satisfied by sufficient cause. ${ }^{27}$

\section{Power of tribunal}

The Tribunal shall have same power as are vested in a civil court under The code of civil procedure,1908, for trying any suit and matter relating to summoning and examining on oath , discovery and production of document, receiving evidence on affidavit, requestioning any public record or document or copy from any office (under section 123 and 124 of The Indian evidence act, 1872), reviewing own decision, dismissing application, setting aside any order, pass any interim order or permanent order to resist the person from causing any violation of any enactment specified in Schedule-1 or any other matter. ${ }^{28}$

This Act also provide mandatory power to The tribunal regulate its own procedure, While tribunal dealing with proceeding under section 193,213 and 228 for the purpose of section 196 of The Indian Penal Code 1860, this proceeding shall be as a judicial proceeding and tribunal shall be deemed as a civil court for the purpose of section 195 and Chapter-26 of The Code of Criminal procedure 1973. The Tribunal shall have power of civil court relating to execution of decree, order, or decision. ${ }^{29}$ While passing the decree, order or decision the

\footnotetext{
${ }^{24}$ Sec. $15(2)$ of The NGT Act, 2010.

${ }^{25}$ Sec. $15(3)$ of The NGT Act, 2010.

${ }^{26}$ Sec. 29 of The NGT Act2010.

${ }^{27}$ Sec. 22 of The NGT Act 2010 .

${ }^{28}$ Sec. 19 of The NGT Act 2010.

${ }^{29}$ Sec. $25(1)$ of The NGT Act 2010.
}

tribunal shall apply the principle of sustainable development, the precautionary principle and the polluter pay principle. ${ }^{30}$

\section{Conclusion}

India is the only nation to have introduced an environmental tribunal after Australia and Newzealand. It was constituted to provide redressal to aggrieved person in matters relating to environment .While settling the dispute and questions the tribunal has been vested with power to grant compensation, damages, relief also for the direct restitution of environment. The NGT of India has developed faith in society till date and achieved success in delivering environmental justice. During the disposal of cases and delivery of justice, NGT is the first body in India to apply the polluter pay principle, the precautionary principle and sustainable development principle. The NGT has grown in multidisciplinary dimensions and makes great contribution to the development of environmental jurisprudence not only in national level but also in (internationally) global level. At present, NGT has done well in easy and inexpensive access to justice but some improvements are still required to litigant satisfaction and sustainable development. The issue of environmental or climate change is more serious, the government should make it more autonomous in the field of jurisdiction and rule making power.

\section{Necessity for additional reform}

i. NGT should have provides more powers in the field of jurisdiction and infrastructure and these power should be subject of judicial review. ${ }^{31}$

ii. Other country law (which is beneficial) related to environment should also be included with in the ambit of NGT Act 2010.

iii. It also needs to apply certain effective system along with traditional, so justice can achieve at grass root level.

iv. The check and balance method should be improvised to free and fair delivery of justice'

v. The Government should Co-operate with national green tribunal on centre, state and in local level.

vi. Suo-motu jurisdiction must provide to NGT on every step and level to maintain the environmental balance.

vii. It needs to identify the experts and institution for the help of NGT in the matters related to estimation of compensation, damages and fine on the basis of complicated matter on cases. ${ }^{32}$

\section{Acknowledgments}

None.

\section{Conflicts of interest}

The author declares that there are no conflicts on interest.

\footnotetext{
${ }^{30}$ Sec. 20 of The NGT Act 2010.

${ }^{31}$ Reason behind that "Power tends to corrupt and absolute power corrupt absolutely." quoted by lord Atkin.

${ }^{32}$ Finding on the basis of case, In A.P. Pollution Control board v. MV Nayadu 1992 (2) SCC 718 the Supreme Court referred to need for establishing special court to benefitted by expert advice through environmental scientist or technically qualified person.
} 